\section{The History of Lunacy and the scholarship of Edward H. Hare}

HENRY R. ROLLIN

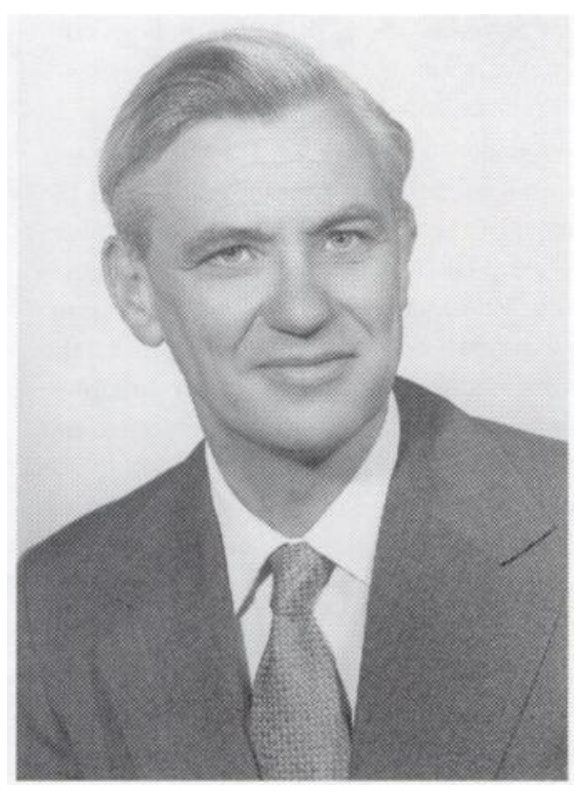

Fig. I Edward H. Hare (photograph reproduced with the kind permission of Mrs Fiby Hare).

This editorial has been prompted by the publication of a slim, elegantly produced volume, celebrating the achievement of one of the most illustrious contemporary British psychiatrists, Edward H. Hare (Hare, 1998). That it has been produced in less than two years after his death is a living tribute to the devotion and editorial skills of his close friend, John Crammer (who succeeded Hare as editor of the British Joumal of Psychiatry in 1978), and the love and unflagging assistance, in a multitude of ways, of Fiby, Hare's wife for his last 26 years.

I had the good fortune to be presented with a copy of the book and also received a four-page leaflet entitled 'Publications of E. H. Hare'. It is a formidable compilation detailing over 120 publications, the vast majority written as sole author, and serves as an illustration of the profundity of his scholarship, the catholicism of his interests as well, of course, of his highvoltage intelligence. For our convenience, his publications are grouped under nine broad headings: historical, clinical and metabolic, neurological, pharmacotherapy and physical, social psychiatry, epidemiological/demographical. It continues with a list of publications, chapters in books, articles for non-specialists and finally, editorial works.

It follows from this vast oeuvre that the selection of what is to be included in this book presents far more difficulty than what is to be excluded. However, John Crammer has risen splendidly to the occasion, and his skills as an editor plus his intimate knowledge of the material have allowed him to select only eight papers which, collectively, suffice to give us the flavour of Hare's unique writings.

The predominant feature emerging from the picture of Hare is primarily of a scientist, but of a scientist capable of subjecting his data to sophisticated statistical analysis. The result of this fine tuning is that detail in his data begins to emerge which would have escaped the attention of the less observant - which includes, in effect, the vast majority of us less-gifted mortals. A prime example is to be seen in his well-known hypothesis which argues that schizophrenia taken with the season of birth dates pointed to the possibility that the onset of mental illness was a delayed after-effect of a viral infection in foetal life.

In Chapter 1, 'The changing content of psychiatric illness', we see Hare as a clinician, epidemiologist and historian par excellence. Nothing expresses his philosophy more aptly and more succinctly than his final few lines. He writes:

"But I do want to suggest to you that psychiatric disorders are changing all the time, that we ought to be carefully monitoring these changes, and that we should at least keep in mind the possibility that part of these changes, and perhaps a considerable part, are due to secular processes of a sort which have too often been considered as only peripheral to the conventional concerns of medicine".

The same gospel according to Edward Hare is expounded in his masterly Chapter 3, 'The origin and spread of dementia paralytica'. In this he expounds his belief that at the end of the 15th century, the syphylitic virus underwent a mutation resulting in changes in symptomatology as well as anatomical/pathological changes. He further maintains that in the past 140 years or so, the disease has shown gradual modifications in clinical form and a recent natural decline in prevalence. It is most important to emphasise Hare's firm conviction is that the rise and fall and, on occasion, the disappearance of disease, somatic or mental, arises independently of the advances in treatment.

We have seen that Dr Hare can wear a variety of caps, each of them with considerable panache. For the last paper in this book, Chapter 8, 'Masturbatory insanity: the history of an idea', Hare dons his deer-stalker. In this exposé, he reveals, if nothing else, the unbelievable naivety of first-class thinkers of the 19th century as, for example, our own Henry Maudsley, probably the best philosopher/psychiatrist of his time. Hare in his best Sherlockian manner explodes the myth of masturbatory insanity which these great men so fervently supported. He demolishes the myth, gently but firmly, so ". . . the evidence, is that the association between masturbation and mental disorder is weak and inconstant and that therefore, if masturbation is a causal factor, it is probably not a very important one".

Edward Hare has left behind him no traditional memorials; no marble busts, no painting in oil, no eponymous lecture. However, steeped as I have been for some long time in his magisterial, self-assured writing, I am firmly of the opinion that any such memorial is quite superfluous - his writing is his own memorial.

\section{REFERENCE}

Hare, E. H. (1998) History of Lunacy: The 19th Century and After. London: Gabbay.

Henry R. Rollin, FRCPsych, 101 College Road, Epsom, Surrey KT17 4HY

(First received 6 November 1998, final revision 4 January 1999, accepted 18 January 1999) 